\title{
Pengetahuan dan Sikap Remaja Anak Jalanan tentang Dismenore Primer dan Senam Dismenore di Komunitas Peduli Anak Jalanan Medan
}

\author{
Nur Asnah Sitohang ${ }^{1,},{ }^{*}$ Diah Lestari Nasution ${ }^{2}$ \\ 1,2Fakultas Keperawatan, Universitas Sumatera Utara, Jl. Prof. T. Maas No. 3, Medan, Indonesia \\ ${ }^{1}$ sitohangnurasnah@gmail.com*; ${ }^{2}$ diah.lestari@usu.ac.id \\ * corresponding author
}

ARTICLE INFO

Article history

27-08-2021

$19-09-2021$

03-10-2021

Keywords

Street children

Primary dysmenorrhea

Dysmenorrhea gymnastics

\begin{abstract}
Primary dysmenorrhea is defined as cramping pain in the lower abdomen that occurs at the start of menstruation in the absence of identifiable pelvic disease. It is one of the most common gynecological symptoms among adolescents and adult women with a prevalence of $45 \%-95 \%$. Overproduction of uterine prostaglandins is the most widely accepted explanation for the pathogenesis. Excessive release of prostaglandins, especially prostaglandin F2 alpha, which is derived from endometrial secretions from menstrual fluid, is believed to cause the condition. Primary dysmenorrhea has different degrees of negative impact on women's physical, psychological and social functioning, which can result in adolescent and adult women being out of school and absent from work. The purpose of this study was to identify the knowledge and attitudes of street children towards primary dysmenorrhea and dysmenorrhea exercise. The research design is descriptive. The sampling technique is total sampling. The number of samples is 45 people. The sample criteria for street children are teenage girls aged 10-18 years, unmarried, already menstruating, can read and write well. Data analysis is descriptive. The results of the study obtained that the majority of street children's knowledge of adolescents was good (53.3\%), dysmenorrhea intensity was moderate pain with a score range of 4-7 (68.9\%) and adolescent attitudes were negative (71.1\%). Knowledge of respondents still needs to be improved to form a positive attitude. It is recommended to the head of KOPA to cooperate with health workers to conduct health education about primary dysmenorrhea on a regular basis to adolescent street children.
\end{abstract}

\section{Pendahuluan}

Dismenore primer didefinisikan sebagai nyeri kram di perut bagian bawah yang terjadi pada awal menstruasi tanpa adanya penyakit panggul yang dapat diidentifikasi. Ini adalah salah satu gejala ginekologi yang paling umum di kalangan remaja dan wanita dewasa dengan prevalensi $45 \%-95 \%$ [1][2]. Kelebihan produksi prostaglandin uterus adalah penjelasan yang paling banyak diterima untuk patogenesis. Pelepasan prostaglandin yang berlebihan, terutama prostaglandin F2 alfa, yang berasal dari sekresi endometrium dari cairan menstruasi, diyakini menyebabkan kondisi tersebut [3].

Dismenore primer memiliki tingkat dampak negatif yang berbeda pada fungsi fisik, psikologis dan sosial wanita, yang dapat menyebabkan remaja dan wanita dewasa tidak sekolah dan absen dari pekerjaannya [4][5]. Meskipun prevalensi tinggi di antara remaja dan wanita muda di seluruh dunia, dismenore primer sering diperlakukan dengan buruk dan bahkan diabaikan oleh profesional kesehatan, peneliti nyeri dan wanita itu sendiri [6]. Perawatan diri didefinisikan sebagai 
aktivitas praktik yang dimulai dan dilakukan individu atas nama mereka sendiri dalam mempertahankan kehidupan, kesehatan, dan kesejahteraan [7].

Tindakan perawatan diri yang diadopsi oleh anak perempuan dengan dismenore primer bervariasi di seluruh negara.Penelitian melaporkan bahwa 58\%-70\% remaja dinegara Barat mengobati sendiri dengan mengkonsumsi obat antiinflamasi nonsteroid dan obat analgesik [8][9]. Hasil penelitian pada remaja di Asia menunjukkan bahwa mayoritas gadis Asia menyatakan tidak bersedia mengggunakan obat untuk mengatasi dismenore primer karena mereka khawatir tentang ketergantungan dan efek sampingnya [10]. Strategi lain yang digunakan untuk remaja putri dalam menjaga kehangatan tubuhnya selama mengalami dismenorea primer adalah modifikasi diet, terapi panas, minuman hangat, tidur, terapi pijat [11][12].

Faktor penyebab dan yang berisiko mengalami dismenorea primer adalah: (1) alkohol, alkohol merupakan racun bagi tubuh dan hati. Fungsi hati terganggu karena mengkonsumsi alkohol terus menerus. Penumpukan estrogen yang dikeluarkan tubuh akibat mengkonsumsi alkohol menyebabkan gangguan pada pelvis, (2) rokok, merokok dapat meningkatkan lamanya menstruasi dan dismenore, (3) tidak pernah berolahraga, kejadian dismenore akanmeningkatdengankurangnya aktifitas selama menstruasi. Hal ini dapat menyebabkan sirkulasi darah dan oksigen menurun. Dampak pada uterus adalah aliran darah dan sirkulasi oksigen pun berkurang dan menyebabkan nyeri, (4) stres, stress menimbulkan penekanan sensasi saraf-saraf pinggul dan otot-otot punggung bawah sehingga menyebabkan dismenore [13].

Selain dengan obat-obatan, dismenorea bisa dikurangi dengan: (1 istirahat yang cukup, (2) olahraga yang teratur (terutama berjalan), (3) pemijatan, (4) yoga atau senam dismenorea, (5) orgasme pada aktivitas seksual, (6) kompres hangat di daerah perut [14]. Senam dismenore merupakan aktivitas fisik yang dapat digunakan untuk mengurangi nyeri. Senam yang dilakukan menghasilkan hormone endorfin. Hormon endorphin yang semakin tinggi akan menurunkan atau meringankan rasa nyeri yang dirasakan sehingga seseorang menjadi lebih nyaman, gembira, dan melancarkan pengiriman oksigen ke otot [15].

Mengatasi dismenore bisa dengan melakukan kegiatan olahraga. Olahraga menyebabkan tubuh banyak bergerak sehingga memperlancar aliran darah dalam tubuh dan merangsang tubuh memproduksi hormon endorfin. Hormon endorfin bekerja mengurangi rasa sakit dan menimbulkan rasa gembira [16].

Tujuan senam disemenore yaitu: (1) membantu remaja yang mengalami dismenore untuk mengurangi dan mencegah dismenore, (2) alternatif terapi dalam mengatasi dismenore, (3) intervensi yang dapat diterapkan untuk memberikan pelayanan asuhan keperawatan bagi remaja dengan masalah dismenore, (4) memberikan pengalaman baru bagi remaja [15].

Populasi remaja rentang usia 12-17 tahun, dismenore memiliki prevalensi 59,7\%. Skala nyeri yang dilaporkan $12 \%$ menggambarkannya sebagai berat, $37 \%$ ringan, dan $49 \%$ ringan. Dismenore menyebabkan $14 \%$ pasien sering melewatkan sekolah. Penelitian tentang efektivitas senam terhadap dismenorea di SMAN 2 Padang Panjang diperoleh hasil terjadi penurunan skala nyeri [17][18].

\section{Metode}

Tujuan penelitian ini adalah untuk mengidentifikasi pengetahuan dan sikap remaja anak jalanan terhadap dismenore primer dan senam dismenore. Desain penelitian adalah deskriptif. Teknik pengambilan sampel adalah total sampling. Jumlah sampel 45 orang. Kriteria sampel: remaja putri anak jalanan berusia 10-18 tahun, belum menikah, sudah mengalami menstruasi, bisa baca tulis dengan baik. Analisis data adalah deskriptif. 


\section{Hasil danDiskusi}

Tabel 3.1. Distribusi Frekuensi dan Persentase Karakteristik Responden Remaja Anak Jalanan terhadap Dismenorea Primer di Komunitas Peduli Jalanan Medan $(\mathrm{n}=45)$

\begin{tabular}{|c|c|c|}
\hline Karakteristik & Frekuensi & Persentase (\%) \\
\hline \multicolumn{3}{|l|}{ Umur } \\
\hline 10 & 4 & 8,8 \\
\hline 11 & 6 & 13,3 \\
\hline 12 & 7 & 15,6 \\
\hline 13 & 7 & 15,6 \\
\hline 14 & 8 & 17,8 \\
\hline 16 & 4 & 8,9 \\
\hline 17 & 5 & 11,1 \\
\hline 18 & 4 & 8,9 \\
\hline Total & 45 & 100 \\
\hline \multicolumn{3}{|l|}{ Pendidikan } \\
\hline SD & 17 & 37,8 \\
\hline SMP & 15 & 33,3 \\
\hline SMA & 13 & 28,9 \\
\hline Total & 45 & 100 \\
\hline \multicolumn{3}{|l|}{ Usia haid pertama kali } \\
\hline 9 & 3 & 6,7 \\
\hline 10 & 5 & 11,1 \\
\hline 11 & 7 & 15,6 \\
\hline 12 & 12 & 26,7 \\
\hline 13 & 11 & 24,4 \\
\hline 15 & 7 & 15,6 \\
\hline Total & 45 & 100 \\
\hline \multicolumn{3}{|l|}{ Pendidikan Orang tua } \\
\hline SMP & 7 & 15,6 \\
\hline SMA & 30 & 66,7 \\
\hline SARJANA & 8 & 17,8 \\
\hline Total & 45 & 100 \\
\hline \multicolumn{3}{|l|}{ Pekerjaan Orang tua } \\
\hline Ibu rumah tangga & 10 & 22,2 \\
\hline Wiraswasta & 25 & 55,6 \\
\hline Asisten rumah tangga & 5 & 11,1 \\
\hline Guru & 3 & 6,7 \\
\hline Satpam & 2 & 4,4 \\
\hline Total & 45 & 100 \\
\hline \multicolumn{3}{|l|}{ Mengalami Nyeri Haid } \\
\hline Iya & 45 & 100 \\
\hline Total & 45 & 100 \\
\hline $\begin{array}{l}\text { Pembalut } \\
\text { digunakan }\end{array}$ & 45 & 100 \\
\hline \multicolumn{3}{|l|}{ Pembalut komersial } \\
\hline Total & 45 & 100 \\
\hline \multicolumn{3}{|l|}{ IMT } \\
\hline Kurus & 22 & 48,9 \\
\hline Normal & 20 & 44,4 \\
\hline Overweight & 3 & 6,7 \\
\hline Total & 45 & 100 \\
\hline \multicolumn{3}{|l|}{ Riwayat Alergi } \\
\hline Ada & 9 & 20,0 \\
\hline Tidak ada & 36 & 80,0 \\
\hline Total & 45 & 100 \\
\hline
\end{tabular}




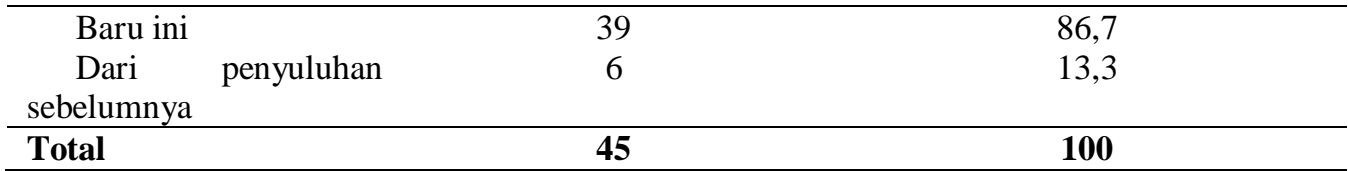

Berdasarkan tabel 3.1.di atas diperoleh data mayoritas remaja berusia 14 tahun $(17,8 \%)$, pendidikan SD $(37,8 \%)$, usia menarche 12 tahun $(26,7 \%)$, pendidikan orang tua SMA $(66.7 \%)$, pekerjaan orang tua wiraswasta $(55,6 \%), 100 \%$ mengalami dismenorea, $100 \%$ jika mengalami haid menggunakan pembalut komersial (yang dijual di toko), status gizi (IMT) kurus (48,9\%), tidak memmiliki riwayat alergi $(80 \%)$ dan baru mendapai informasi tentang dismenorea melalui kegiatan PKM ini $(86,7 \%)$.

Tabel 3.2. Distribusi Frekuensi dan Persentase Pengetahuan Remaja Anak Jalanan terhadap Dismenorea Primer di Komunitas Peduli Jalanan Medan ( $\mathrm{n}=45)$

\begin{tabular}{llcccc}
\hline \multirow{2}{*}{ No Pertanyaan } & \multicolumn{2}{c}{ Benar } & \multicolumn{2}{c}{ Salah } \\
\cline { 3 - 6 } & & f & $\mathbf{\%}$ & f & \% \\
\hline 1 & Nyeri yang terdapat menjelang atau selama haid & 23 & 51,1 & 23 & 48,9 \\
\hline 2 & $\begin{array}{l}\text { Nyeri haid cenderung terjadi lebih sering dan lebih hebat pada } \\
\text { wanita yang mengalami kegelisahan }\end{array}$ & 14 & 31,1 & 31 & 68,9 \\
\hline 3 & Usia wanita yang biasanya sering terjadi nyeri haid & 44 & 97,8 & 1 & 2,2 \\
\hline 4 & Akibat yang terjadi saat timbulnya nyeri haid & 30 & 66,7 & 15 & 33,3 \\
\hline 5 & Gangguan yang sering terjadi menjelang haid secara fisik & 23 & 51,1 & 22 & 48,9 \\
\hline 6 & Penyebab terjadinya nyeri haid & 33 & 73,3 & 12 & 26,7 \\
\hline 7 & Faktor penyebab terjadinya nyeri haid & 28 & 62,2 & 17 & 37,8 \\
\hline 8 & Nyeri yang terjadi selama haid & 30 & 66,7 & 15 & 33,3 \\
\hline 9 & Klasifikasi nyeri haid & 34 & 75,6 & 11 & 24,4 \\
\hline 10 & Tanda dan gejala nyeri haid & 36 & 80,0 & 9 & 20,0 \\
\hline 11 & Penyakit penyerta nyeri haid & 21 & 46,7 & 24 & 53,3 \\
\hline 12 & $\begin{array}{l}\text { Nyeri haid yang menurun sesuai bertambahnya usia dan } \\
\text { biasanya berhenti setelah melahirkan }\end{array}$ & 20 & 44,4 & 25 & 55,6 \\
\hline 13 & $\begin{array}{l}\text { Nyeri haid yang mengganggu kegiatan sehari-hari dan dapat } \\
\text { dikurangi dengan meminum obat-obatan }\end{array}$ & 34 & 75,6 & 11 & 24,4 \\
\hline 14 & Penanganan nyeri haid & 31 & 68,9 & 14 & 31,1 \\
\hline 15 & Penanganan yang dapat mengurangi nyeri haid & 29 & 64,4 & 16 & 35,6 \\
\hline
\end{tabular}

Berdasarkan tabel 3.2. diperoleh data remaja paling banyak dijawab salah adalah nyeri haid cenderung terjadi lebih sering dan lebih hebat pada wanita yang mengalami kegelisahan $(68,9 \%)$, nyeri dismenorea menurun sesuai bertambahnya usia $(55,6 \%)$, komplikasi dismenorea $(53,3 \%)$, waktu terjadinya dismenorea $(48,8 \%)$, defenisi dismenorea $48,9 \%$.

Tabel 3.3. Distribusi Frekuensi dan Persentase Kategori Pengetahuan Remaja Anak Jalanan terhadap Dismenorea Primer di Komunitas Peduli Jalanan Medan ( $\mathrm{n}=45)$

\begin{tabular}{ccc}
\hline Variabel & Frekuensi (f) & Persentase (\%) \\
\hline Baik & 24 & 53,3 \\
Cukup & 16 & 35,6 \\
Kurang & 5 & 11,1 \\
\hline Total & $\mathbf{4 5}$ & $\mathbf{1 0 0}$ \\
\hline
\end{tabular}

Berdasarkan tabel 3.3. diperoleh data mayoritas pengetahuan remaja anak jalanan berada pada kategori baik $(53,3 \%)$ dan masih ada $(11,1 \%)$ kurang. 
Tabel 3.4. Distribusi Frekuensi dan Persentase Intensitas DismenorePrimer Remaja Anak Jalanan di Komunitas Peduli Jalanan Medan ( $\mathrm{n}=45)$

\begin{tabular}{lcc}
\hline Intensitas Nyeri & Frekuensi (f) & Persentase (\%) \\
\hline Nyeri Ringan & 11 & 24,4 \\
Nyeri Sedang & 31 & 68,9 \\
Nyeri Berat & 3 & 6,7 \\
\hline Total & $\mathbf{4 5}$ & $\mathbf{1 0 0}$ \\
\hline
\end{tabular}

Berdasarkan tabel 3.4.diperoleh data mayoritas intensitas dismenore yang dialami anak remaja yang diukur menggunakan skala nyeri 0-10 (numeric scale) adalah nyeri sedang rentang skor $4-7(68,9 \%)$.

Tabel 3.5

Distribusi Frekuensi dan Persentase Sikap Remaja Anak Jalanan terhadap Dismenorea Primer di Komunitas Peduli Jalanan Medan ( $\mathrm{n}=45)$

\begin{tabular}{|c|c|c|c|c|c|c|c|c|c|}
\hline \multirow[t]{2}{*}{ No } & \multirow[t]{2}{*}{ Pernyataan } & \multicolumn{2}{|c|}{ STS } & \multicolumn{2}{|c|}{ TS } & \multicolumn{2}{|c|}{$\mathbf{S}$} & \multicolumn{2}{|c|}{ SS } \\
\hline & & f & $\%$ & f & $\%$ & $\mathbf{F}$ & $\%$ & $\mathbf{F}$ & $\%$ \\
\hline 1 & $\begin{array}{l}\text { Nyeri haid merupakan hal } \\
\text { yang menakutkan bagi } \\
\text { remaja putri }\end{array}$ & 2 & 4,4 & 20 & 44,4 & 20 & 44,4 & 3 & 6,7 \\
\hline 2 & $\begin{array}{l}\text { Nyeri haid terjadi karena } \\
\text { adanya perubahan hormonal } \\
\text { pada remaja putri }\end{array}$ & 2 & 4,4 & 2 & 4,4 & 28 & 62,2 & 13 & 28,9 \\
\hline 3 & $\begin{array}{l}\text { Kurang gizi adalah salah satu } \\
\text { penyebab nyeri haid }\end{array}$ & 0 & 0 & 7 & 15,6 & 29 & 64,4 & 9 & 20,0 \\
\hline 4 & $\begin{array}{l}\text { Nyeri haid } \text { sangat } \\
\text { mengganggu aktivitas sehari- } \\
\text { hari walaupun hanya nyeri } \\
\text { ringan }\end{array}$ & 3 & 6,7 & 6 & 13,3 & 28 & 62,2 & 8 & 17,8 \\
\hline 5 & $\begin{array}{l}\text { Nyeri haid membuat remaja } \\
\text { putri tidak ingin melakukan } \\
\text { aktivitas apapun termasuk } \\
\text { sekolah dan belajar }\end{array}$ & 6 & 13,3 & 25 & 55,6 & 8 & 17,8 & 6 & 13,3 \\
\hline 6 & $\begin{array}{l}\text { Jika mengalami nyeri haid } \\
\text { saya akan melakukan } \\
\text { pemeriksaan ke dokter atau } \\
\text { tenaga kesehatan lainnya }\end{array}$ & 11 & 24,4 & 28 & 62,2 & 6 & 13,3 & 0 & 0 \\
\hline 7 & $\begin{array}{l}\text { Jika mengalami nyeri haid } \\
\text { saya akan menceritakan pada } \\
\text { ibu saya }\end{array}$ & 0 & 0 & 0 & 0 & 23 & 51,1 & 22 & 48,9 \\
\hline 8 & $\begin{array}{l}\text { Jika mengalami nyeri haid } \\
\text { saya akan mengonsumsi } \\
\text { makanan bergizi dan minum } \\
\text { air hangat }\end{array}$ & 0 & 0 & 2 & 4,4 & 24 & 53,3 & 19 & 42,2 \\
\hline 9 & $\begin{array}{l}\text { Jika terjadi nyeri haid saya } \\
\text { akan minum obat }\end{array}$ & 8 & 17,8 & 32 & 71,1 & 3 & 6,7 & 2 & 4,4 \\
\hline 10 & $\begin{array}{l}\text { Nyeri haid adalah hal yang } \\
\text { wajar dialami wanita karena } \\
\text { proses fisiologis }\end{array}$ & 0 & 0 & 0 & 0 & 37 & 82,2 & 8 & 17,8 \\
\hline 11 & $\begin{array}{l}\text { Jika terjadi nyeri haid, } \\
\begin{array}{l}\text { seharusnya } \\
\text { welakukan aktivitas }\end{array}\end{array}$ & 2 & 4,4 & 3 & 6,7 & 32 & 71,1 & 8 & 17,8 \\
\hline 12 & $\begin{array}{l}\text { Setiap wanita perlu } \\
\text { mengetahui penyebab } \\
\text { terjadinya nyeri haid }\end{array}$ & 0 & 0 & 0 & 0 & 23 & 51,1 & 22 & 48,9 \\
\hline 13 & $\begin{array}{l}\text { Jika saya mengalami nyeri } \\
\text { haid saya akan pergi ke }\end{array}$ & 16 & 35,6 & 26 & 57,8 & 3 & 6,7 & 0 & 0 \\
\hline
\end{tabular}




\begin{tabular}{|c|c|c|c|c|c|c|c|c|c|}
\hline & $\begin{array}{lr}\text { tukang pijat untuk dipijat } \\
\text { bagian perut } & \text { yang } \\
\text { mengalami nyeri/kram } & \end{array}$ & & & & & & & & \\
\hline 14 & $\begin{array}{l}\text { Jika mengalami nyeri haid } \\
\text { saya akan melakukan } \\
\text { kompres panas diatas perut }\end{array}$ & 3 & 6,7 & 5 & 11,1 & 26 & 57,8 & 11 & 24,4 \\
\hline 15 & $\begin{array}{l}\text { Setiap wanita perlu } \\
\text { mengetahui tanda dan gejala } \\
\text { nyeri haid }\end{array}$ & 0 & 0 & 3 & 6,7 & 29 & 64,4 & 13 & 28,9 \\
\hline 16 & $\begin{array}{l}\text { Nyeri haid primer akan } \\
\text { hilang setelah } 2-24 \text { jam }\end{array}$ & 3 & 6,7 & 10 & 22,2 & 32 & 71,1 & 0 & 0 \\
\hline 17 & $\begin{array}{l}\text { Nyeri haid primer akan } \\
\text { muncul satu hari sebelum } \\
\text { haid atau setelah haid }\end{array}$ & 0 & 0 & 8 & 17,8 & 29 & 64,4 & 8 & 17,8 \\
\hline 18 & $\begin{array}{lrr}\text { Jika mengalami } & \text { nyeri haid } \\
\text { saya akan melakukan } \\
\text { olahraga yaitu } & \text { senam } \\
\text { dismenorea } & & \\
\end{array}$ & 3 & 6,7 & 3 & 6,7 & 28 & 62,2 & 11 & 24,4 \\
\hline 19 & $\begin{array}{l}\text { Senam dismenorea dapat } \\
\text { menurunkan } \\
\begin{array}{l}\text { menghilangkan nyeri haid } \\
\text { primer }\end{array}\end{array}$ & 3 & 6,7 & 3 & 6,7 & 26 & 57,8 & 13 & 28,9 \\
\hline 20 & $\begin{array}{l}\text { Jika nyeri haid yang saya } \\
\text { alami tidak hilang setelah } \\
\text { melakukan olahraga saya } \\
\text { akan konsultasi ke petugas } \\
\text { kesehatan yang terdekat }\end{array}$ & 0 & 0 & 27 & 60 & 10 & 22,2 & 8 & 17,8 \\
\hline
\end{tabular}

Berdasarkan tabel 3.5. diperoleh data masih ada remaja bersikap negatif terhadap dismenorea yaitu sangat setuju bahwa nyeri haid membuat remaja putri tidak ingin melakukan aktivitas apapun termasuk sekolah dan belajar $(13,3 \%)$, tidak setuju jika terjadi nyeri haid seharusnya wanita melakukan aktivitas $(6,7 \%)$, jika mengalami nyeri haid akan melakukan olahraga yaitu senam dismenore $(6.7 \%)$.

Tabel 3.6. Distribusi Frekuensi dan Persentase Kategori Sikap Remaja Anak Jalanan terhadap Dismenore Primer di Komunitas Peduli Jalanan Medan $(n=45)$

\begin{tabular}{ccc}
\hline Variabel & Frekuensi (f) & Persentase (\%) \\
\hline Positif & 13 & 28,9 \\
Negatif & 32 & 71,1 \\
\hline Total & $\mathbf{4 5}$ & $\mathbf{1 0 0}$ \\
\hline
\end{tabular}

Berdasarkan tabel 3.6. diperoleh data mayoritas sikap remaja anak jalanan berada pada kategori negatif $(71,1 \%)$ dengan kategori positif $(28,9 \%)$.

Hasil penelitian menunjukkan bahwa dari 45 responden remaja anak jalanan, sebagian besar responden memiliki pengetahuan baik yaitu sebanyak 53,3\%, 35,6\% responden berpengetahuan cukup, dan masih ada yang memiliki pengetahuan $11,1 \%$. Pengetahuan adalah hasil tahu dan hal tersebut terjadi sesudah seseorang mengadakan penginderaan terhadap suatu objek tertentu. Penginderaan kepada objek initerjadi melalui pancaindra manusia yaitu penglihatan, pendengaran, penciuman, perasa dan peraba dengan sendiri. Pada waktu penginderaan sampai menghasilkan pengetahuan tersebut sangat dipengaruhi oleh intensitas perhatian persepsi kepada suatu objek. Sebagian besar pengetahuan manusia diperoleh melalui mata dan telinga yakni melalui apa yang mereka lihat dan mereka dengar [19].

Pengetahuan seseorang terhadap suatu objek memiliki intensitas atau tingkatan yang berbeda-beda, secara garis besar dibagi menjadi dalam 6 tingkatan pengetahuan antara lain: tahu, memahami, aplikasi, analisa, sintesis, evaluasi, dan berbagai macam cara untuk mendapatkan pengetahuan sepanjang sejarah dikelompokkan menjadi dua, yaitu: dengan cara tradisional dan 
cara ilmiah. Faktor yang mempengaruhi pengetahuan ada dua,yakni faktor internal yang mana meliputi pendidikan, pengalaman, umur, dan faktor eksternal yang diliputi oleh sosial ekonomi, kebudayaan, media massa, dan sumber daya [19].

Pngetahuan yang baik pada remaja dapat ditentukan oleh beberapa faktor dan salah satunya ialah sumber informasi.Semakin banyak sumber informasi yang diperoleh maka semakin banyak pengetahuan yang dimiliki oleh remaja sehingga dapat memperoleh informasi-informasi yang diperlukan. Sumber informasi yang diperoleh sangat berpengaruh terhadap pengetahuan remaja terhadap suatu objek atau masalah yang dialaminya salah satunya pengetahuan tentang dismenore,karena remaja harus benar-benar mengetahui tentang dismenoreyang normal maupun abnormal agar terhindardari komplikasi atau kelainan dalam sistem dan organreproduksinya[20]. Dari 45 responden yang diperoleh hasil pengetahuan baik yakni sebanyak $24(53,3 \%)$ responden dengan yang masih memiliki pengetahuan kurang yaitu sebanyak $5(11,1 \%)$ responden, dimana sebanyak 45 responden telah mendapatkan pendidikan kesehatan yaitu tentang dismenorea, dengan hasil data pada karakteristik responden mayoritas 39 (86,7\%) responden menyatakan mendapat sumber informasi tentang dismenorea baru ini, dan selebihnya sebanyak $6(13,3 \%)$ responden mendapatkan sumber informasi tentang dismenorea dari penyuluhan sebelumnya.

Pengetahuan dari responden mengalami peningkatan yang signifikan setelah diberikan pendidikan kesehatan. Meningkatnya pengetahuan pada kelompok eksperimen bias terjadi dikarenakan proses pendidikan kesehatan yang diberikan dengan cara dua arah, yaitu informasi yang kurang dipahami oleh responden dapat ditanyakan kembali. Jawaban yang diberikan dengan bahasa yang mudah dimengerti ternyata lebih mudah dipahami oleh responden daripada harus menggunakan bahasa kesehatan yang mungkin sulit dipahami oleh responden [21].

Pengetahuan yang cukup tidak hanya didukung oleh pengalaman yang ada tetapi juga dipengaruhi oleh lingkungan dan informasi yang dapat diperoleh. Pengetahuan yang masih kurang pada remaja anak jalanan di Komunitas Peduli Jalanan Medan tentang dismenorea dapat disebabkan karena kurangnya pengalaman dan pengaruh pergaulan di lingkungan yang kurang bisa memanfaatkan media massa untuk memperoleh informasi tentang kesehatan. Hal ini sejalan dengan penelitian [23], dimana hasil penelitian menunjukkan dari 68 siswi sebagian besar memiliki tingkat pengetahuan cukup sebanyak 37 siswi $(54,4 \%)$, sedangkan hampir setengahnya memiliki pengetahuan baik sebanyak 27 siswi (39,7\%), sisanya sebagian kecil memiliki pengetahuan yang kurang sebanyak 4 siswi $(5,9 \%)$.

Pengetahuan tentang dismenore yang umum bisa diperoleh seperti dari sumber non medis, seperti keluarga, teman dan guru. Nyeri haid yang biasa dirasakan juga dapat diperkuat dengan berbicara dengan anggota keluarga perempuan (seperti ibu atau saudara perempuan) dan teman sebaya karena kemungkinan besar mereka juga mengalami dismenore. Pengetahuan tentang dismenore yang mana mencakup hal mengatasi dismenore dan gejala dismenore ialah sebagai satu kesatuan dari kehidupan wanita yang umum yang mengalami dismenore, hal tersebut konsisten dengan konsep bahwa perempuan "mengumpulkan" gagasan dan pengetahuan tentang periode normal (dismenore) dari pengalaman mereka sendiri [24].

Hasil penelitian dari 45 responden remaja anak jalanan, diperoleh data mayoritas sikap remaja anak jalanan berada pada kategori negatif yaitu sebanyak $32(71,1 \%)$ responden dengan kategori positif sebanyak $13(28,9 \%)$ responden. Sikap ialah reaksi atau respon seseorang yang masih tertutup terhadap suatu stimulus atau objek.Melalui sikap dapat memahami proses kesadaran yang menentukan tindakan nyata dan tindakan yang mungkin dilakukan individu dalam kehidupan sosial. Sikap terdiri dari berbagai tingkatan yakni: menerima (receiving), merespon (responding), menghargai (valuing), dan bertanggung jawab (responsible). Faktor-faktor yang dapat mempengaruhi sikap terhadap objek sikap antara lain, yaitu: pengalaman pribadi, pengaruh orang lain yang dianggap penting, pengaruh kebudayaan, media massa, lembaga pendidikan dan agama, serta faktor emosional [25].

Hasil penelitian yang telah dilakukan kepada 45 responden sebagian besar memiliki sikap yang masih negatif yakni sebanyak 32 responden $(71,1 \%)$. Pengalaman dan penelitian terbukti bahwa sikap yang didasari oleh pengetahuan akan lebih langgeng daripada sikap yang tidak didasari oleh pengetahuan. Kurangnya sikap remaja putri dalam menangani dismenore ketika 
menstruasi terjadi dikarenakan kurangnya kesadaran remaja putri dalam mengetahui penyebab, gejala, dan cara penanganannya, sehingga remaja putri tidak pernah memeriksakan ke petugas kesehatan. Selain itu, kurangnya ketertarikan untuk mencari informasi mengenai dismenore sehingga remaja putri kurang mengetahui perilaku penanganan dismenore yang baik.

Sikap dipengaruhi oleh beberapa faktor salah satunya ialah pengalaman pribadi yang mana remaja sudah mengalami dismenorea. Semakin banyak pengalaman dismenorea pada remaja tersebut maka akan semakin besar pula rasa ingin tahu remaja tersebut untuk menanganinya. Selain pengalaman pribadi, faktor lain yang mempengaruhi sikap ialah sumber informasi dari orang tua, media massa sebagai sarana untuk komunikasi, berbagai bentuk media massa untuk mendapatkan informasi seperti: televisi, radio, surat kabar, majalah, dll. Jadi, semakin banyak informasi yang diperoleh remaja tentang dismenore maka semakin luas pengetahuan dari remaja tersebut, sehingga dengan pengetahuan tentang dismenore yang baik maka remaja akan memiliki sikap yang baik pula, sebaliknya jika remaja memiliki pengetahuan yang rendah tentang dismenorea maka akan terbentuk sikap yang negatif [25].

Terkait dengan fakta remaja putri memiliki lebih banyak kesempatan untuk mendapatkan informasi medis yakni dari saran orang tua, teman, apoteker, surat kabar atau majalah populer dan internet. Namun, sedikit penelitian yang telah dilakukan dismenore pada remaja yang hidup di negara maju. Sebaiknya untuk lebih memperhatikan masalah kesehatan masyarakat ini dan untuk mempromosikannya kepada warga negara tentang kesadaran tentang risiko yang terkait dengan konsumsi obat tanpa konsultasi medis, dan untuk mendidik remaja dan wanita muda untuk mencari dan mendapatkan perawatan yang profesional ketika mereka mengalami dismenore yang sedang hingga berat dan dapat menanganinya [26].

\section{Kesimpulan}

Hasil penelitian menunjukan bahwa mayoritas pengetahuan remaja anak jalanan berada pada kategori baik $(53,3 \%)$ dan masih ada $(11,1 \%)$ kurang, intensitas dismenore adalah nyeri sedang rentang skor 4-7 $(68,9 \%)$ dan mayoritas sikap remaja berada pada kategori negatif $(71,1 \%)$ dengan kategori positif (28,9\%). Pengetahuan responden masih perlu ditingkatkan untuk membentuk sikap positif.Untuk itu disarankan kepada ketua KOPA agar menjalin kerjasama dengan petugas kesehatan untuk melakukan pendidikan kesehatan tentang dismenore secara rutin kepada remaja anak jalanan.

\section{Ucapan Terima Kasih}

Sumber pendanaan kegiatan ini adalah NON PNBP Universitas Sumatera Utara sesuai dengan Surat Perjanjian Penugasan Pelaksanaan Pengabdian kepada Masyarakat Program Mono Tahun Reguler Tahun Anggaran 2020 Nomor : 184/UN5.2.3.2.1/PPM/2021, Tanggal 7 Juni 2021, untuk itu kami mengucapkan terima kasih kepada bapak rektor, Wakil Rektor 3 dan Ketua LPPM USU.

\section{Referensi}

[1] Proctor M, Farquhar, C. Diagnosis and management of dysmenorrhea. BMJ 2006; 332:11348. 2006.

[2] Al-Kindi R, Al-Bulushi A. Prevalence and impact of dysmenorrhoea among Omani high school students. Sultan Qaboos Univ Medical Journal. 11:485-91. 2011.

[3] Dawood MY. Primary dysmenorrhea: advances in pathogenesis andmanagement. Obstet Gynecologi. 108:428-41. 2006.

[4] Aktaş D. Prevalence and factors affecting dysmenorrheal infemale university students: effect on general comfort level. Pain Manag Nurse. 16:534-43. 2015.

[5] Titilayo A, Agunbiade OM, Banjo O, etal. Menstrual discomfort and its influence on daily academic activities and psychosocial relationship among undergraduate female students in 
Nigeria. Tanzan Journal Health Research. 11:181-8. 2009.

[6] Iacovides S, AvidonI, Baker FC. What we know about primary dysmenorrheal today: a critical review. Human Reproductive Update 2015;21:762-78. 2015.

[7] Orem DE. Nursing: Concepts of practice. $5^{\text {th }}$ edn. St.Louis: Mosby-Yearbook. 2001.

[8] Polat A, Celik H, Gurates B, et al. Prevalence of primary dysmenorrheal in young adult female university students. Arch Gynecology Obstetri. 279:527-32. 2009.

[9] Campbell MA, McGrath PJ. Use of medication by adolescents for the management of menstrual discomfort. Arch Pediatric Adolescence Medic. 151:905-13. 1997.

[10] Wong CL, IP WY, Lam LW. Self-care strategies among Chineseadolescent girls withdysmenorrhea: aqualitative study.Pain Management Nursing. 17:262-71. 2016.

[11] Cheng H-F, Lin Y-H. Selection and efficacy of self-management strategies for dysmenorrheal in young Taiwan esewomen. Journal Clinic Nursing. 20:1018-25. 2011.

[12] Aziato L, Dedey F, Clegg-Lamptey JNA. Dysmenorrhea management and coping among students in Ghana: aqualitative exploration. Journal Pediatric Adolescne Gynecology. 28:163-9. 2015.

[13] Hendrik. Problem haid : tinjauan syariah Islam dan media. PT. Tiga Serangkai Pustaka Mandiri. Solo. 2006.

[14] Nugroho. T. U. B. Masalah Kesehatan Reproduksi Wanita. Yogyakarta: Nuha Medika. 2014.

[15] Sugani. P. Cara Cerdas untuk Sehat: Rahasia Hidup Sehat Tanpa Dokter. Jakarta: Transmedia. 2010.

[16] Sinaga. E. Manajemen Kesehatan Menstruasi. Iwwash: Jakarta. 2017.

[17] Calis, K. A. Dysmenorrhea. https://emedicine.medscape.com/article/253812-overview, Diakses pada tanggal 28 Maret 2021.

[18] Deharnita, T. S. W. Mengurangi Nyeri dengan Senam Dismenore. Jurnal PARALLELA1(1). 2014.

[19] Notoatmodjo. Ilmu Perilaku Kesehatan. Jakarta: PT. Rineka Cipta. 2010.

[20] Susiloningtyas, L. Hubungan Pengetahuan Remaja Putri tentang Dismenore dengan Sikap Penanganan Dismenore. Embrio, Jurnal Kebidanan.Vol.X No.I,45-52. 2018.

[21] Gumilar, R.A. Pengaruh Pendidikan Kesehatan Terhadap Perubahan Tingkat Pengetahuan dan Sikap Remaja Putri tentang Penanganan Dismenore di SMPN 2 Kartasura". Artikel Publikasi Ilmiah. Fakultas Ilmu Kesehatan Universitas Muhammadiyah Surakarta. 2014.

[22] Haerani et all. Deskripsi Pengetahuan Remaja Putri tentang Dismenore di Kelurahan Benjala Kecamatan Bontobahari Kabupaten Bulukumba. Jurnal Penelitian Kedokteran dan Kesehatan. 2(2), 197-206. 2020.

[23] Wilandania, E. Gambaran Tingkat Pengetahuan Remaja Putri tentang Gangguan Menstruasi Pada Siswi Kelas XI di SMAN 13 Surabaya. University of Nahdlatul Ulama Surabaya. KTI. 2015.

[24] Armour, M, dkk. Self-care strategies and sources of knowledge on menstruation in 12, 526 young women with dysmenorrhea: A systematic review and meta-analysis. PLOSONE. 1-18. https://doi.org/10.1371/journal.pone.0220103. 2019.

[25] Dewi., Wawan., Teori dan Pengukuran Pengetahuan, Sikap dan Perilaku Manusia. Yogyakarta: Nuha Medika. 2011.

[26] Sanctis, Vetall. Prevalence, attitude and practice of self-medication among adolescents and the paradigm of dysmenorrhea self-care management in different countries. Acta Biomed.Vol.91, N.1:182-192. DOI:10.23750/abm.v91i1.9242. 2020. 